\title{
Considerations in the Development of Live Biotherapeutic Products for Clinical Use
}

Jennifer J. Ross*, Philip E. Boucher**, Siba P. Bhattacharyya ${ }^{\ddagger}$, Dennis J. Kopecko ${ }^{\ddagger}$, Elizabeth M. Sutkowski*, Patricia J. Rohan*, Donna K.F. Chandler*, and Julienne Vaillancourt*

*Division of Vaccines and Related Products Applications and ${ }^{\ddagger}$ Division of Bacterial, Parasitic and Allergenic Products Office of Vaccines Research and Review (OVRR), Center for Biologics Evaluation and Research (CBER), Food and Drug Administration (FDA), Rockville, MD

**Novartis Vaccines and Diagnostics

1, Via Fiorentina

Siena 53100, ITALY

\begin{abstract}
Food products in the United States (U.S.), including dietary supplements, may contain live microorganisms and can be promoted for general health, nutritional, or structure/function claims. In contrast, such preparations used with the intention of having a preventive or therapeutic effect in humans are regulated by the Food and Drug Administration (FDA) in the U.S. as biological products, specifically as live biotherapeutic products (LBPs). Discussion of considerations in the early development of LBPs may aid in preparation of an Investigational New Drug Application (IND) that is designed to collect clinical data to support marketing approval of a LBP in the U.S. for a specific clinical use. Product information is an important component of an IND to support a proposed clinical study.
\end{abstract}

\section{Introduction}

This article is intended to provide an overview of the regulatory issues in the U.S. for early development (Phase 1) of a live biotherapeutic product intended for use in the treatment or prevention of human disease.

The term live biotherapeutic product (LBP) refers to products containing whole, live microorganisms (i.e., bacteria, yeast) with an intended therapeutic or preventive effect in humans, regardless of the route of administration (oral, intravaginal, topical, etc.) (Ross, 2006; Vaillancourt, 2006). LBPs may contain commensal microorganisms isolated from a human host and/or recombinant microorganisms. For example, most food (FD\&C Act, 1938) and dietary supplement (DSHEA, 1994) products containing members of genera Lactobacillus and/or Bifidobacterium, could be developed as LBPs (Tannock 2003).

Intended use determines how FDA regulates a substance. The terms drug (FD\&C Act, 1938) and biological product (PHS Act, 1944), are regulatory terms relating to use of a substance. Legal definitions of regulatory terms are summarized here. A drug is an article intended for use in the diagnosis, cure, mitigation, treatment, or prevention of human disease. A biological product is any virus, therapeutic serum, toxin, anti-toxin, or analogous product applicable to the prevention, treatment or cure of diseases or injuries of man and covered by the FD\&C Act. Thus, a biological product is defined as a drug. In addition, historically, "virus" referred to minute living causes of infectious disease. The definition of a virus in this context encompasses products containing microorganisms such as bacteria and fungi.

Currently, FDA's Center for Biologics Evaluation and Research (CBER) regulates live biotherapeutic products. A LBP may undergo clinical development for potential licensure, i.e., marketing approval, in the U.S. for a specific clinical use based on supportive safety and efficacy data from clinical trials. Typically, a LBP is evaluated for a specific clinical use in FDA-reviewed clinical trials designed to evaluate safety and efficacy conducted under an IND (Part 312, 2006). Chemistry, manufacturing and control (CMC) information is an important component of an IND to support a proposed clinical study.

\section{Chemistry, Manufacturing and Control (CMC)}

Significant overlap exists for CMC requirements between LBPs and vaccines, as both may be live bacterial products. Guidance documents describing vaccine IND submissions (Guidance for Industry, 1995) and other relevant material on CBER's website, http://www.fda.gov/cber/guidelines. $h t m$, may be consulted.

A dietary supplement or other food component proposed for use in the treatment or prevention of human disease may not have undergone sufficient product development to support an IND application. In particular, it is not adequate for a LBP evaluated in a clinical study under IND to be manufactured according to the less stringent current Good Manufacturing Practices (cGMP) for food (Part 110, 2006). A common 
misconception is that microorganisms designated as GRAS (Generally Recognized As Safe) for specified food use (Part 170, 2006) are automatically safe for use as a component of a drug or biological product; however, food terms do not apply to biological products.

If the sponsor of an IND is not the manufacturer of the LBP, then the sponsor may discuss arrangements for the submission of CMC information with the manufacturer prior to IND submission. CMC information obtained from the manufacturer can be submitted by the IND sponsor as part of the IND. Alternatively, CMC information can be submitted separately by the manufacturer in a Master File (MF) (Part $314.420,2006)$ to CBER. Typically, a MF is used when the manufacturer deems details of the CMC in whole or in part as intellectual property, or the product is evaluated under multiple INDs.

\section{Product Characterization}

Detailed information regarding source and history of the microorganism(s), such as strain passage from the original isolate to the current stock, is critical for the evaluation of a product to be used in a proposed clinical study under IND. The health status of the host, whether human or animal and diseased or healthy, from which the microorganism was derived and the methods and media used in propagation should also be provided. It is insufficient to merely cite intermediary sources such as procurements through commercial providers.

Phenotypic and genotypic characterizations are critical components used to arrive at an informed assessment of LBP safety. If the organism has been genetically modified, then details of the genetic constructions should be provided. In addition, investigation of alternative approaches available for selection or maintenance of genetic modifications, i.e., those lacking antibiotic resistance genes, is encouraged. Biochemical characterization performed prior to a Phase 1 clinical study should include, but not be restricted to, methods for identification, antibiotic sensitivity/resistance profile (using the actual drug product microorganism), presence of transmissible genetic elements, and analysis of residual or masked virulence. Information obtained on the LBP's mechanism of action(s) at an early stage can be extremely useful for drug development, e.g., in selecting potency assays.

\section{Manufacturing}

An IND should contain certificates of analyses for all raw materials used in manufacturing, including documentation for bovine, ovine, or other animal-derived products used at any stage in isolation, passage, or manufacture (Restrictions..., 1998). Although not required prior to Phase 1, sponsors are encouraged to establish a working cell bank(s) as soon as possible in development to ensure that the supply of investigational product is not depleted before clinical studies are completed.

A critical aspect of product development is implementation of a manufacturing process that is controlled and assures that a product can be manufactured in a reproducible, consistent manner. It is recommended that manufacturers implement cGMP for biological products (Part $210-211,2006)$ as early as possible. In particular, safety related elements of biologic cGMP are expected to be implemented prior to initiation of a Phase 1 clinical study, and include, but are not limited to, proper identification of source material, a description of master and any working cell banks, a detailed description of the manufacturing process, determination of extraneous bioburden, safety testing, and applicable adventitious agent testing. Results from inprocess and lot release testing to demonstrate the safety, purity and potency of the product are expected to be available prior to initiation of a Phase 1 study. Lot release testing protocols and results (raw data within specified ranges, not just pass/fail) used to ensure safety, identity, purity, absence of contaminating microorganisms (bioburden) and potency should be provided for the clinical lot(s) intended for use. Early in development, cell viability (ratio of live to dead cells) may generally be thought to reflect LBP potency. However, an alternative biochemical or physicochemical measurement may be identified during product development that more accurately predicts potency and may then be employed as a potency assay, e.g., production of an antimicrobicide by a microorganism. The Microbial Limit Tests (U.S. Pharmacopeia, 2007), is generally suggested for determination of product contamination or extraneous bioburden and to assess the absence of known pathogens. An issue relevant to LBP manufacture is the importance of demonstrating that detection of contaminating microorganism(s) is possible given the large number of product microorganisms. Final Quality Control and Quality Assurance measures are rarely in place prior to the initiation of a Phase 1 study, as these systems are expected to be incrementally refined as product development proceeds. Prior to Phase 3 clinical studies, lot release tests and specifications are expected to 
be in compliance with regulations on general biological product standards (Part 610, 2006).

\section{Final Drug Product}

The final drug product(s) for use in nonclinical and clinical studies are expected to be described in an IND, including wellcharacterized excipients, adjuvants, stabilizers, and buffers along with the quantities per dose or concentrations with the dosage stated. Differences and similarities to products used in any nonclinical and clinical studies submitted in support of a proposed IND clinical study should be well-described.

Stability testing is conducted in order to establish expiry dating (shelf-life). At a minimum, the LBP should be stable for a period of time equal to the duration of the proposed Phase 1 clinical investigation. Tests used for lot release are often utilized in stability testing, including tests for potency, microbial bioburden/contamination, and when applicable, moisture and $\mathrm{pH}$. In some cases, a LBP is reconstituted and stored refrigerated by study personnel and/or a study participant or caregiver for a length of time. In this case, the LBP should be tested to ensure stability under actual storage and use conditions, not only as stored prior to reconstitution.

The placebo product for use in a clinical study should also be described in an IND. Careful consideration should be given to the choice of placebo. Use of a killed bacterial species or strain is not usually a suitable placebo, since ingredients contained in the killed product may contribute to systemic reactogenicity or contribute to activity/efficacy.

\section{Conclusion}

When products containing live microorganisms are administered with the intention of treating or preventing human diseases in the U.S., then such proposed use exceeds the definition of a dietary supplement or other type of food product and instead meets the definition of a biological product, i.e., a live biotherapeutic product (LBP). Evaluation of a LBP in the prevention and treatment of human disease in the U.S. should be established by rigorous and careful development in accordance with established U.S. regulatory pathways. Development of CMC information contributes much to the success of clinical investigations conducted under IND.

\section{Acknowledgements and Disclaimer}

We thank colleagues for their review of this work, including Drs. Marion Gruber, Karen Goldenthal, Paul Richman, Jon Daugherty, and Carmen Collazo. The findings and conclusions in this article have not been formally disseminated by the FDA and should not be construed to represent any Agency determination or policy.

\section{References}

1. DSHEA (Dietary Supplement Health Education Act )of 1994

2. FD\&C Act (Food, Drug and Cosmetic Act) amendment of 1938 and revisions (21 U.S.C. 301 et seq).

3. Guidance for Industry. "Content and Format of Investigational New Drug Applications (INDs) for Phase 1 Studies of Drugs, Including Well-Characterized, Therapeutic, Biotechnology-derived Products", 1995. [Online.] http://www.fda.gov/cber/guidelines.htm

4. Part 110 Current Good Manufacturing Practice in Manufacturing, Packing, or Holding Human Food. US. Code of Federal Regulations 2006, Chapter 21.

5. Part 170 Food Additives. US. Code of Federal Regulations 2006, Chapter 21.

6. Part 210-211Current Good Manufacturing Practice. U.S. Code of Federal Regulations 2006, Chapter 21

7. Part 312 Investigational New Drug Application. US. Code of Federal Regulations 2006, Chapter 21.

8. Part 314.420 Drug Master Files. US. Code of Federal Regulations 2006, Chapter 21.

9. Part 610 General Biological Products Standards. U.S. Code of Federal Regulations, 2006, Chapter 21.

10. Public Health Service (PHS) Act, July 1, 1944, Chap. 373, Title III, Sec. 351, 58 Stat. 702 , currently codified at 42 U.S.C., Sec. 262.

11. Restrictions on the importation of ruminants, meat, and meat products from ruminants, and certain other ruminant products. (1998) Federal Register; 63 (3): 406-408, docket 97-127-1.

12. Ross, J. (2006) Regulatory Considerations. In American Society for Microbiology Colloquium Report Probiotic Microbes: The Scientific Basis.

(Washington, DC: American Academy of Microbiology), p.8. 
13. Tannock, G. (2003). Probiotics: Time for a Dose of Realism. Curr Issues Intest Microbiol. 4, 33-42.

14. U.S. Pharmacopeia, USP28-NF24 2007 $<61>$, Microbial Limit Tests. [Online.] http://www.usp.org/

15. Vaillancourt, J.(2006) Regulating Pre-and Pro-biotics: A US FDA Perspective. In Institute of Medicine Report of the Forum on Microbial Threats Workshop Summary. Ending the War Metaphor: The Future Agenda for Unraveling the Host-Microbe Relationship. (Washington, DC: National Academies Press), pp. 229-237. 


\section{Further Reading}

Caister Academic Press is a leading academic publisher of advanced texts in microbiology, molecular biology and medical research. Full details of all our publications at caister.com

- MALDI-TOF Mass Spectrometry in Microbiology Edited by: M Kostrzewa, S Schubert (2016) www.caister.com/malditof

- Aspergillus and Penicillium in the Post-genomic Era Edited by: RP Vries, IB Gelber, MR Andersen (2016) www.caister.com/aspergillus2

- The Bacteriocins: Current Knowledge and Future Prospects Edited by: RL Dorit, SM Roy, MA Riley (2016)

www.caister.com/bacteriocins

- Omics in Plant Disease Resistance Edited by: V Bhadauria (2016) www.caister.com/opd

- Acidophiles: Life in Extremely Acidic Environments Edited by: R Quatrini, DB Johnson (2016) www.caister.com/acidophiles

- Climate Change and Microbial Ecology: Current Research and Future Trend

Edited by: J Marxsen (2016)

www.caister.com/climate

- Biofilms in Bioremediation: Current Research and Emerging Technologies

Edited by: G Lear (2016)

www.caister.com/biorem

- Microalgae: Current Research and Applications Edited by: MN Tsaloglou (2016) www.caister.com/microalgae

- Gas Plasma Sterilization in Microbiology: Theory, Applications, Pitfalls and New Perspectives Edited by: H Shintani, A Sakudo (2016) www.caister.com/gasplasma

- Virus Evolution: Current Research and Future Directions Edited by: SC Weaver, M Denison, M Roossinck, et al. (2016) www.caister.com/virusevol

- Arboviruses: Molecular Biology, Evolution and Control Edited by: N Vasilakis, DJ Gubler (2016) www.caister.com/arbo

- Shigella: Molecular and Cellular Biology Edited by: WD Picking, WL Picking (2016) www.caister.com/shigella

-Aquatic Biofilms: Ecology, Water Quality and Wastewater Treatment

Edited by: AM Romaní, H Guasch, MD Balaguer (2016)

www.caister.com/aquaticbiofilms

- Alphaviruses: Current Biology

Edited by: S Mahalingam, L Herrero, B Herring (2016)

www.caister.com/alpha

- Thermophilic Microorganisms

Edited by: F Li (2015)

www.caister.com/thermophile
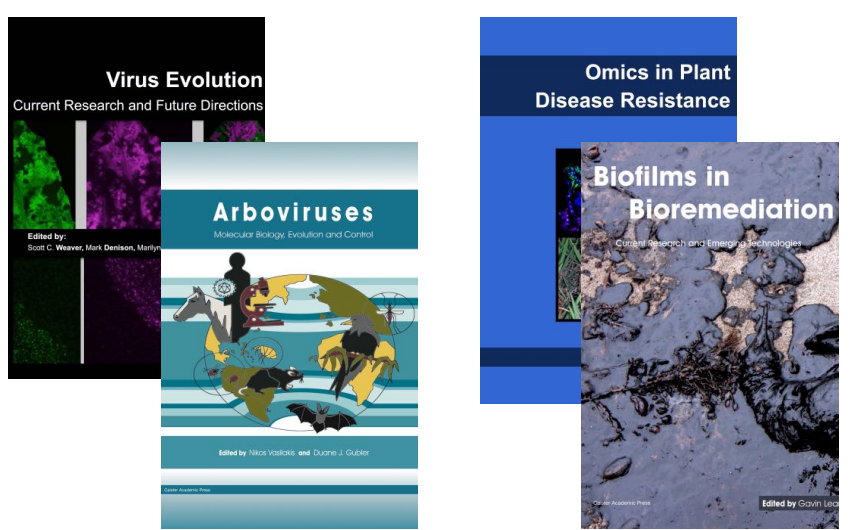
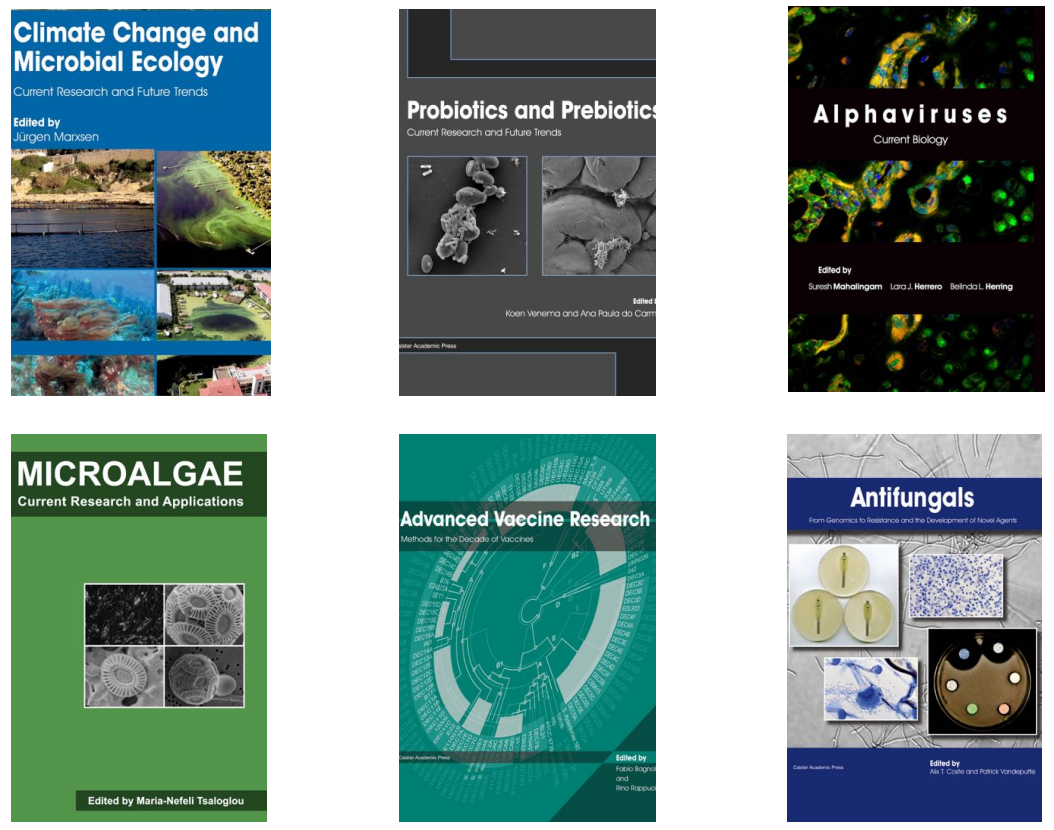

- Flow Cytometry in Microbiology: Technology and Applications Edited by: MG Wilkinson (2015) www.caister.com/flow

- Probiotics and Prebiotics: Current Research and Future Trends Edited by: K Venema, AP Carmo (2015) www.caister.com/probiotics

- Epigenetics: Current Research and Emerging Trends Edited by: BP Chadwick (2015) www.caister.com/epigenetics2015

- Corynebacterium glutamicum: From Systems Biology to Biotechnological Applications

Edited by: A Burkovski (2015)

www.caister.com/cory2

- Advanced Vaccine Research Methods for the Decade of Vaccines

Edited by: F Bagnoli, R Rappuoli (2015)

www.caister.com/vaccines

- Antifungals: From Genomics to Resistance and the Development of Novel Agents

Edited by: AT Coste, P Vandeputte (2015)

www.caister.com/antifungals

- Bacteria-Plant Interactions: Advanced Research and Future Trends Edited by: J Murillo, BA Vinatzer, RW Jackson, et al. (2015) www.caister.com/bacteria-plant

\section{- Aeromonas}

Edited by: J Graf (2015)

www.caister.com/aeromonas

- Antibiotics: Current Innovations and Future Trends

Edited by: S Sánchez, AL Demain (2015)

www.caister.com/antibiotics

- Leishmania: Current Biology and Contro Edited by: S Adak, R Datta (2015) www.caister.com/leish2

- Acanthamoeba: Biology and Pathogenesis (2nd edition) Author: NA Khan (2015)

www.caister.com/acanthamoeba2

- Microarrays: Current Technology, Innovations and Applications Edited by: Z He (2014)

www.caister.com/microarrays2

- Metagenomics of the Microbial Nitrogen Cycle: Theory, Methods and Applications

Edited by: D Marco (2014)

www.caister.com/n2 